\title{
Public and Private Partnership as a Mechanism of Government and Business Cooperation
}

\author{
Bulnina I.S. ${ }^{a}$ \\ Askhatova L.I. ${ }^{\text {. }}$ \\ Kabasheva I.A. ${ }^{c}$ \\ Rudaleva I.A.d \\ a bcd Kazan Federal University, Institute of Management, Economics and Finance, Kazan, 420008, Russia \\ Email: ibulnina@gmail.com
}

\section{Doi:10.5901/mjss.2015.v6n1s3p453}

\section{Abstract}

The state represented by bodies of regional and local authorities with the help of public-private partnership projects will be able to move from direct budgetary financing of projects to a promising model for attracting private funds, thereby increasing the efficiency of their operations. There is a need to strengthen the system of interaction between government and the private sector, as it will lead to the creation of conditions for increasing the competitiveness of the public sector through more effective use of state property, investment in the economy, modernization of industrial and social infrastructure, improving the quality of goods, works and services.

Keywords: public-private partnership, power, money, competitiveness, investment, improving the quality, the transport industry

\section{Introduction}

Public and private partnership is a specific instrument allowing government bodies and entrepreneurship to enter entirely a new state of relationship.

In recent times, our country consolidates its position on the world market and increases its capabilities, government officials modernize legislation, overarching priorities for national development are established, and attention is meanwhile directed to private sector, without which it is hard to imagine development of any government. In current economical and political development conditions of Russia, that are PPP projects that may come the substantial instrument assisting in escaping challenging situation. Government, in the name of regional and municipal authorities, can pass from direct budgetary financing to advanced model of private fund raising due to PPP, projects, whereby improving the efficiency of its activity.

\section{Method}

PPP [5] is cooperation between government authorities and private sector, focused on supplying the needs of sociality, implementation of important public projects, which has institutional composition and implicates balance of convenience for private and state parties.

Present definition of PPP alludes various forms of public and private parties' cooperation, such as [5]:

- contract system, gained ground in public procurement implementation;

- concession, alluding transfer of government property management to the private sector upon terms of upgrading, reconstruction with reserved property rights;

- cooperation between private and public parties through building joint ventures.

Close links between government and entrepreneurship, in one way or other, promote appearing different antilogies, private and public interests come into conflict. These antilogies can be narrowed down the following [5]:

1) First variant is that interests of business community supersede public interests. This is represented as ambitions of private sector members to get highest possible unilateral economic effect from PPP projects implementation; 
2) The second variant of imbalance in relations between government and entrepreneurship is, in contrast, associated with suppression of private sector interests, which is involved in or express a desire of taking part in implementation of important public projects.

\section{Result}

Analyzing PPP projects of some foreign countries, comprising governments of different development levels, one may conclude that, for the moment, PPP is extensively used in transport industry (this concerns engineering and upgrading of roads, railways, airports, waterway ports), social infrastructure (solution of healthcare, medicine, secondary and higher education, travel industry), municipal housing economy (water supply services, electric supply services, water purification and filtration) and others (prisons, national defense etc.). Most projects are presented in transport and social industries.

Analysis of using PPP mechanism abroad has shown that each country has any industry, where the use of PPP is widespread and priority-oriented [4]. In economically developed countries with sufficiently high living standards and active social policy performed by the government, PPP projects are generally implemented in healthcare, education, social security sectors. Such sectors in emerging countries with transition economy, except for transport industry, will never be strategically important for the government.

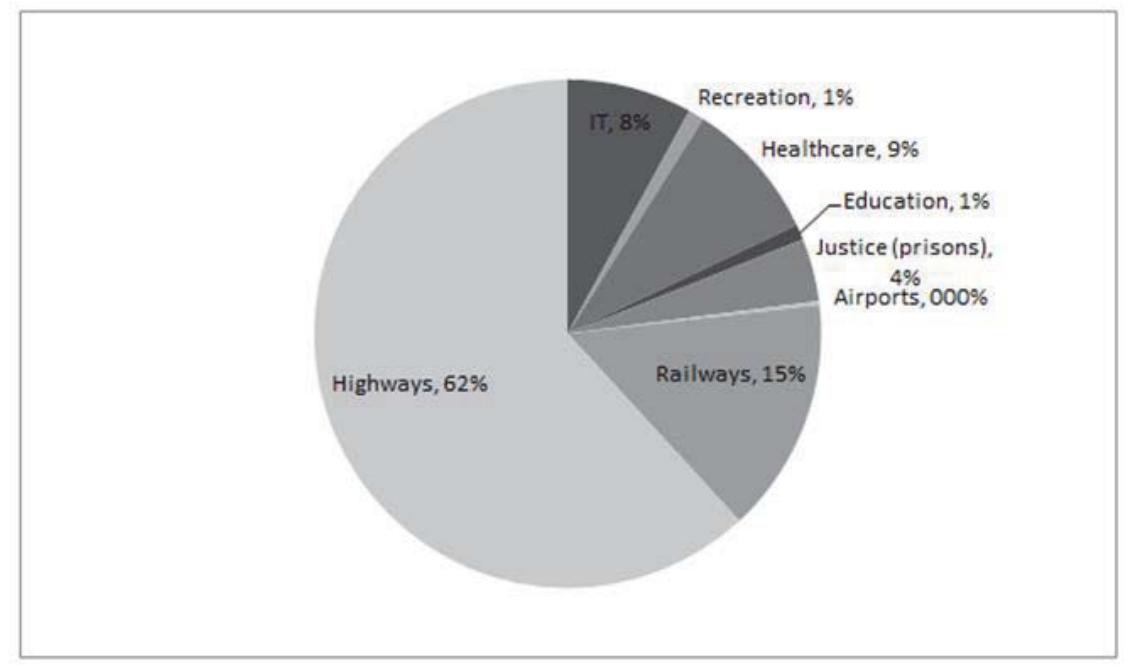

Source: Federal Highway Administration

Fig. 1 Use of PPP mechanisms in European transport projects

- Market risk (restraint of demand etc.)

- Reduction in yield risk

- Payment risks

- Engineering overrating

- Exploitation risks

- Long-range investments underestimation

- Credit exposure (dormant commitments of credits, delinquency of sum required)

- Terms of compensation and exit scenario
- Legal developments

- Economical change

- Exchange risks

- Tax risks

- Loss of assets management

- Policy risks (instability, protectionism, nonacceptance of project by society)

- Ecological risks

- Transaction costs

- Management/contract risks

Fig. 2. Basic kinds of project risks related to the use of Public and private partnership

Federal Law № 115 "Concerning Concession Agreements" enacted on July 21, 2005 established legal framework for appliance of concessions as one of the efficient methods of Russian public property appliance [2]. Its purpose is fundraising for Russian economy. However, legislative framework for active cooperation between business and government is 
not developed at all; this determines imperfection of this institute in this country. That is why projects are not implemented in such amounts as in foreign countries.

One of the current trends of concessional practice is economic growth of regions. Among approved at the moment PPP projects, it is necessary to accentuate several largest automotive and infrastructural programs in Moscow, St. Petersburg, Eastern Siberia, and also two largest projects in modern Russian history on industrial zones development in Lower Angara region (Krasnodar Territory) and Nizhnekamsk (RT) [6]. Majority of projects are in progress at the moment. PPP mechanism produces lively exchange between researchers and government officials and private sector.

Analysis of PPP mechanism realization has shown major obstacles in the way of its development. For instance, development of this mechanism is retarded by default in details and uncertainty of regulatory framework, exposure of private sector interests, high administrative burdens associated with bureaucratic red-tape and massive officials' corruptness.

\section{Conclusion}

Actually, there is a need for consolidation of interaction system of government and private sector, as this may lead to setting the stage for competitive growth of public sector by more efficient use of public property, fund-raising for economy, industrial and social infrastructures, goods, work and services refinement.

Growth of confidence to each of the parties is a lengthy process, mutual consideration for appeals, development of necessary regulatory framework, honesty and integrity will promote the development of PPP mechanism.

\section{References}

Budget Code for the Russian Federation. M .: INFRA 2008.

Federal Law № 115 "Concerning Concession Agreements" I/ Izvestiya. 2005.

Varnavskiy, VG Partnership between the government and the private sector: forms, projects, risks / VG Varnavskiy. M .: Nauka, 2005.$315 \mathrm{p}$.

Dansarova, SD Institute of public-private partnership: the formation and development in Russia / C.D. Dansarova. Ulan-Ude: EastSiberia. Tech. University Press, 2007.- $154 \mathrm{p}$.

Evstafyev, EN Public-private partnerships as a factor of innovation development of economy / EN Evstafev.Kazan: KSU, 2010. -203 p.

Badalov, AL Public-private partnership in the implementation of investment projects: AL Badalov // EKO.- 2008, №9-s.129-135.

Varnavskiy, VG Government and business: forms and strategies of interaction: V.G.Varnavsky // World Economy and International otnosheniya.- 2006, №2- s.104-106.

Denisenko, E. How would the PPP / E.Denisenko // Magazine Expert, Internet versiya.- 2012, № 8- mode access URL http://expert.ru/northwest/2012/08/kak-byi-gchp/

Talskaya, M. Forget PPP / M. Talskaya // Magazine Expert, Internet versiya. 2008, №27 http://expert.ru/expert/2008/27/zabut_gchp/

Askhatova L.I., Fatkhiev A.M., Safiullin L.N. and Safiullina A.M. Competitive Strategies Formation in High Technology Enterprise // World Applied Sciences Journal, 27(13), 2013, pp. 20-23.

Klychova G.S., Faskhutdinova M.S., Sadrieva E.R. Budget efficiency for cost control purposes in management accounting system /I Mediterranean Journal of Social Sciences vol. 5 № 24, November 2014, pp. 79-83

Klychova G.S., Kulikova L.I., Mavlieva L.M., Klychova A.S. Organization of accounting in fur farming according to IAS // Mediterranean Journal of Social Sciences vol. 5 № 24, November 2014, pp. 84-90

Melnik, A.N., Lukishina, L.V. (2014). The use of index approach for enterprise energy strategy formation. Mediterranean Journal of Social Sciences, 5 (18 SPEC. ISSUE), pp. 289-292. 